\title{
The C1772T genetic polymorphism in human HIF-1 $\alpha$ gene associates with expression of HIF-1 $\alpha$ protein in breast cancer
}

\author{
HYE OK KIM ${ }^{1,2}$, YONG HWA JO ${ }^{1,2}$, JUHIE LEE ${ }^{3}$, SANG SOOK LEE ${ }^{4}$ and KYUNG-SIK YOON ${ }^{1,2}$ \\ ${ }^{1}$ Department of Biochemistry and Molecular Biology (BK21 project); ${ }^{2}$ Medical Research Center for \\ Bioreaction to Reactive Oxygen Species and Biomedical Science Institute, School of Medicine; \\ ${ }^{3}$ Department of Pathology, School of Medicine, Kyung Hee University, Seoul; \\ ${ }^{4}$ Department of Pathology, College of Medicine, Keimyung University, Daegu, Korea
}

Received June 6, 2008; Accepted July 30, 2008

DOI: 10.3892/or_00000127

\begin{abstract}
Hypoxia-inducible factor 1 (HIF-1) is an important genetic component involved in the cellular response to hypoxia. HIF-1 is also linked to the regulation of tumor development and growth. In previous studies, the C1772T (P582S) or the G1790A (A588T) polymorphisms of the HIF- $1 \alpha$ gene have been identified in renal cell carcinoma, head and neck and esophageal squamous cell carcinomas as well as colorectal and prostate cancers. In our study, we investigated whether polymorphisms of the HIF-1 $\alpha$ gene may account for the expression patterns of HIF- $1 \alpha$ protein and impact of clinical progression in breast cancer. We also examined the impact of prognosis of HIF-1 $\alpha$ gene polymorphism and protein expression in the prediction of biological behavior. We performed polymerase chain reaction and direct sequencing to detect polymorphisms in exon 12 of HIF- $1 \alpha$ from 90 breast cancer patients and 102 healthy controls. The expression of HIF-1 $\alpha$ was measured in paraffinembedded specimens from patients by immunohistochemistry. We associated its expression with known prognostic factors. The frequency of the $\mathrm{T}$ allele for $\mathrm{C} 1772 \mathrm{~T}$ in breast cancer patients and healthy controls was 5.6 vs. $4.4 \%$, whereas, the frequency of the A allele for G1790A was 1.7 vs. $4.4 \%$. HIF- $1 \alpha$ was overexpressed in $56.7 \%$ (51 of 90) of the patients. Its overexpression associated with the T1772 polymorphic allele ( $\mathrm{p}=0.04)$. Elevated levels of HIF-1 $\alpha$ protein were found in cases of breast cancer with lymph node metastasis
\end{abstract}

Correspondence to: Dr Kyung-Sik Yoon, Department of Biochemistry and Molecular Biology (BK21 project), Medical Research Center for Bioreaction to Reactive Oxygen Species and Biomedical Science Institute, School of Medicine, Kyung Hee University, Hoegi-dong, Dongdaemun-gu, Seoul, Korea

E-mail: sky9999@khu.ac.kr

Key words: hypoxia-inducible factor $1 \alpha$, single nucleotide polymorphism, hypoxia-inducible factor $1 \alpha$ expression, breast cancer $(\mathrm{p}=0.041)$, high histological grade $(\mathrm{p}=0.001)$ and increased Ki-67 index $(p=0.031)$. These results suggest the potential use of C1772T (P582S) polymorphism and expression analysis in providing a new prognostic factor for unfavorable disease outcomes and may help for clinical decision-making in the treatment of breast cancer patients.

\section{Introduction}

Hypoxia is defined as an inadequacy of oxygen reaching the body's tissues and is common in many solid tumors, including breast cancer $(1,2)$. A hypoxic microenvironment initiates multiple cellular responses, such as proliferation and angiogenesis, resulting in tumor growth and progression (3). Hypoxia inducible factor-1 (HIF-1) consists of HIF-1 $\alpha$ and HIF-1ß subunits and acts as a transcription activator to mediate cellular responses to hypoxia (4-6). HIF-1 activity is regulated by the oxygen-dependent expression of the HIF- $1 \alpha$ subunit (7). Under normoxic conditions, hydroxylation of Pro402 and Pro564 within the oxygen-dependent degradation domain (ODD) of the HIF-1 $\alpha$ protein leads to the binding of ODD with the von Hippel-Lindau tumor suppressor protein ( $\mathrm{PVHL}$ ). Thereafter, the HIF- $1 \alpha$ protein is rapidly degraded through the pVHL-mediated ubiquitin-proteasome pathway. Under hypoxic conditions, however, the rate of hydroxylation of Pro402 and Pro564 decreases and the HIF-1 $\alpha$ protein accumulates. The HIF-1 $\alpha$ then translocates to the nuclear compartment and activates the transcription of hypoxiainducible gene after binding with HIF-1ß (8).

Previously, two polymorphisms (SNPs designated as C1772T, G1790A) in the ODD domain of the HIF-1 $\alpha$ gene were identified as a base change from $\mathrm{C}$ to $\mathrm{T}$ at 1772 , or $\mathrm{G}$ to A at 1790 (C1772T, G1790A), giving rise to Pro/Ser variation at codon 582 or Ala/Thr variation at codon 588 (P582S, A588T) (9). These missense polymorphisms revealed higher transcription activities than wild-type under normoxic or hypoxic conditions $(10,11)$. Moreover, in the instance of androgen-independent prostate cancer in Caucasians and African-Americans, there is a significant increase in the frequency of the CT or TT genotypes in patients compared to 
healthy controls (12). In contrast, there apparently is no significant genotype difference between patients and controls in colorectal cancer in Japan and Sweden $(13,14)$ and esophageal cancer in China (15). Thus, we have explored the frequency difference of HIF- $1 \alpha$ polymorphism between patients and healthy controls regarding breast cancer in Korea.

The unfavorable prognosis of many tumors is associated with concentration of the HIF-1 $\alpha$ protein (16-18). For breast cancer, an upregulation of HIF-1 $\alpha$ protein was associated with the increased proliferation and poor differentiation, showing an association of HIF-1 $\alpha$ overexpression in the cytoplasm and nuclei of $40-80 \%$ with the more aggressive phenotype $(2,19)$. Although the effect of HIF-1 $\alpha$ polymorphism of expression was specifically studied in an invasive breast cancer patient group in The Netherlands, there was a failure to identify the effect due to an absence of polymorphisms in HIF- $1 \alpha$ overexpressing breast cancer patients (20).

We have evaluated the correlation between HIF- $1 \alpha$ (polymorphisms, expression levels) and clinicopathological features or biomarkers in breast cancer patients in Korea to assess whether HIF-1 $\alpha$ plays a role in the development of breast cancer or serves as a prognostic marker.

\section{Materials and methods}

Patients and healthy subjects. The present study included 90 women who were diagnosed with breast cancer and 102 healthy controls of the same ethnic background as the patients during the years 2000-2007 at the Department of Pathology, Keimyung University Hospital, Daegu and Kyunghee University Hospital, Seoul, Korea. Breast cancer and paired normal tissue samples from the respective patients were collected at hospitalization. Tumors were fixed in formalin and embedded in paraffin. Hematoxylin- and eosinstained histological sections of each case were evaluated for confirmation of the diagnosis. Clinicopathological data included histological type, cancer grade, lymph node status and several biomarkers (ER, PR, HER2, p53 and Ki-67). All patients and healthy controls agreed to genetic testing as approved by the Hospital Institutional Review Board.

Genomic DNA extraction and PCR amplification. Genomic DNA was extracted from solid tissue and blood samples to assess polymorphisms of HIF- $1 \alpha$. The sliced tissue samples were lysed overnight at $56^{\circ} \mathrm{C}$ in a solution containing $20 \mathrm{mM}$ Tris-Cl (pH 8.0), 5 mM EDTA, $400 \mathrm{mM} \mathrm{NaCl}, 1 \%$ SDS and $20 \mathrm{mg} / \mathrm{ml}$ proteinase $\mathrm{K}$ and the DNA extracted using phenol: chloroform:isoamyl alcohol (25:24:1). The Core-One ${ }^{\mathrm{TM}}$ blood genomic DNA isolation kits (Core-Bio System, Seoul, Korea) were used for DNA extraction of case-matched healthy control blood samples according to the manufacturer's instructions. The polymerase chain reaction (PCR) was carried out in a $20 \mu \mathrm{l}$ reaction volume containing $1.5 \mathrm{mmol} / \mathrm{l} \mathrm{MgCl}_{2}$, $40 \mathrm{mmol} / \mathrm{l} \mathrm{KCl}, 10 \mathrm{mmol} / \mathrm{l}$ Tris- $\mathrm{HCl}$ (pH 9.0), $250 \mu \mathrm{mol} / \mathrm{l}$ dNTP, 1 unit Taq DNA polymerase (BIONEER, Daejeon, Korea) and $50 \mathrm{ng}$ genomic DNA in distilled water. PCR was performed to amplify exon 12 of HIF-1 $\alpha$ gene (400 bp fragment) using a primer set. The primer sets were as follows: forward 5'-AAGACACAGAAGCAAAGAAC CCA-3'; reverse 5'-CCATACGGTCTTTTGTCCTGTTT-3.
The conditions for the PCR reaction was denaturation at $95^{\circ} \mathrm{C}$ for $10 \mathrm{~min}$, followed by 35 cycles of denaturation at $95^{\circ} \mathrm{C}$ for $30 \mathrm{sec}$, annealing at $57^{\circ} \mathrm{C}$ for $30 \mathrm{sec}$ and extension at $72^{\circ} \mathrm{C}$ for $30 \mathrm{sec}$, followed by a final extension at $72^{\circ} \mathrm{C}$ for $10 \mathrm{~min}$.

Sequencing. PCR products purified by $95 \%$ ethyl alcohol were used as template DNA for cycle sequencing. The PCR for sequencing was performed using Big Dye Terminator (ver 3.1) cycle sequencer and analyzed using an ABI Prism ${ }^{\circledR} 3730$ Automated DNA sequencer (Applied Biosystems, Foster City, CA).

Tissue microarray construction. To assess the immunoexpression of HIF-1 $\alpha$, we examined tissue microarrays (TMA) which were constructed from specimens of 90 breast cancer patients. Paraffin wax blocks were punched with a $3.0-\mathrm{mm}$ diameter from the selected area in the donor blocks and transferred and arrayed in the recipient blocks using a manual tissue microarray device (UNITMA, Seoul, Korea). The presence of cancer in the arrayed samples was verified on hematoxylin- and eosin-stained sections. Breast cancer tissue samples with strong expression of the protein examined were used as positive controls.

Immunohistochemistry. Immunostaining was performed on $4-\mu \mathrm{m}$ sections. After deparaffination and rehydration, sections were immersed for $10 \mathrm{~min}$ in methanol containing $3 \%$ hydrogen peroxide to block endogenous peroxidase activity. All slides were pretreated with a citrate buffer ( $10 \mathrm{mM}$; $\mathrm{pH}$ 6.0) for antigen retrieval by heating the slides in a microwave oven at $97^{\circ} \mathrm{C}$ for $15 \mathrm{~min}$. A cooling period of $20 \mathrm{~min}$ preceded the incubation of the monoclonal anti-HIF-1 $\alpha$ antibody (clone monoclonal antibody H1a67, NB 100-105; Novus Biologicals, Littleton, CO, USA) diluted $1: 200$ at $4{ }^{\circ} \mathrm{C}$ for overnight. Thereafter, the EnVision ${ }^{\mathrm{TM}}$ systems (Dako, Glostrup, Denmark) were used for HIF- $1 \alpha$ staining according to the manufacturer's instructions. All staining procedures were developed with diaminobenzidine. Before the slides were mounted, all sections were counterstained for $30 \mathrm{sec}$ with hematoxylin and dehydrated in alcohol and xylene.

Tumor cell immunoreactivity was scored according to both the extent of nuclear staining (relative number of HIF-1 $\alpha$ positive cells) and the intensity of the stain reaction by two independent observers (J.H. Lee and S.S. Lee). Only cells with completely darkened nuclear staining were regarded as positive; such nuclear staining was interpreted as an increased levels. The following schema was applied: -, not detected; +, $\leq 5 \%$ positive cells;,$++ 5-10 \%$ weakly to moderately stained cells; +++, 5-10\% intensively stained cells or $10-30 \%$ weakly stained cells. For statistical analysis, the four grades of staining were reduced to the two grades of negative, $(-/+)$ and positive, $(++/+++)$.

Statistical analysis. The Chi-square test (SPSS for windows version 11.5) was used to access correlations of clinicopathological feature (using grade, lymph node status, biomarkers) and HIF- $1 \alpha$ (using polymorphism and expression). P-values of $<0.05$ were regarded as statistically significant. All statistical tests were two-sided. 
Table I. Polymorphism of C1772T and G1790A in breast cancer patients $(n=90)$ and control subjects $(n=102)$.

\begin{tabular}{|c|c|c|c|c|}
\hline Nucleotide & Amino acid & Genotype & Patients (\%) & Controls $(\%)$ \\
\hline \multirow{5}{*}{$\begin{array}{l}\text { C1772T } \\
(\text { rs } 11549465)\end{array}$} & P582S & & $81 \quad(90 \%)$ & $93(91.2 \%)$ \\
\hline & & $\mathrm{CT}+\mathrm{TT}$ & $9(10 \%)$ & $9(8.8 \%)$ \\
\hline & & Allele & Patients (\%) & Controls (\%) \\
\hline & & $\mathrm{C}$ & $170(94.4 \%)$ & $195(95.6 \%)$ \\
\hline & & $\mathrm{T}$ & $10(5.6 \%)$ & $9(4.4 \%)$ \\
\hline Nucleotide & Amino acid & Genotype & Patients (\%) & Controls (\%) \\
\hline \multirow{5}{*}{$\begin{array}{l}\text { G1790A } \\
\text { (rs11549467) }\end{array}$} & A588T & GG & $87(96.7 \%)$ & $94(92.1 \%)$ \\
\hline & & $\mathrm{GA}+\mathrm{AA}$ & $3(3.3 \%)$ & $8 \quad(7.9 \%)$ \\
\hline & & Allele & Patients (\%) & Controls (\%) \\
\hline & & $\mathrm{G}$ & $177(98.3 \%)$ & $195(95.6 \%)$ \\
\hline & & A & $3(1.7 \%)$ & $9(4.4 \%)$ \\
\hline
\end{tabular}

Table II. Frequency of HIF-1 $\alpha$ polymorphism $(\mathrm{C} 1772 \mathrm{~T})$ in a variety of cancers.

\begin{tabular}{|c|c|c|c|c|}
\hline Type of cancer & Genotype & Patients & Controls & Racial group \\
\hline $\begin{array}{l}\text { Breast cancer } \\
\text { (our result) }\end{array}$ & $\begin{array}{l}\mathrm{CC} \\
\mathrm{CT}+\mathrm{TT} \\
\mathrm{CC}\end{array}$ & $\begin{array}{rr}81 & (90 \%) \\
9 & (10 \%) \\
45 & (81.8 \%)\end{array}$ & $\begin{array}{rr}93 & (91.2 \%) \\
9 & (8.8 \%) \\
98 & (89.1 \%)\end{array}$ & $\begin{array}{l}\text { Korean } \\
\text { Japanese }\end{array}$ \\
\hline $\operatorname{HNSCC}^{\mathrm{a}}(10)$ & $\begin{array}{l}\mathrm{CT}+\mathrm{TT} \\
\mathrm{CC}\end{array}$ & $\begin{array}{r}10(18.2 \%) \\
100(100 \%)\end{array}$ & $\begin{array}{l}12(10.9 \%) \\
89 \quad(89 \%)\end{array}$ & Japanese \\
\hline $\mathrm{CRC}^{\mathrm{b}}(13)$ & $\begin{array}{l}\mathrm{CT}+\mathrm{TT} \\
\mathrm{CC}\end{array}$ & $\begin{array}{rr}0 & (0 \%) \\
84 & (88.4 \%)\end{array}$ & $\begin{array}{lr}11 & (11 \%) \\
93 & (89.4 \%)\end{array}$ & Chinese \\
\hline $\operatorname{ESCC}^{c}(15)$ & $\begin{array}{l}\mathrm{CT}+\mathrm{TT} \\
\mathrm{CC}\end{array}$ & $\begin{array}{r}11(11.6 \%) \\
161(82.1 \%)\end{array}$ & $\begin{array}{r}11(10.6 \%) \\
179(91.3 \%)\end{array}$ & $\begin{array}{l}\text { Caucasian and } \\
\text { African-American }\end{array}$ \\
\hline Prostate cancer (12) & $\begin{array}{l}\mathrm{CT}+\mathrm{TT} \\
\mathrm{CC}\end{array}$ & $\begin{array}{rr}35 & (17.9 \%) \\
167 & (84 \%)\end{array}$ & $\begin{array}{rr}17 & (8.6 \%) \\
213 & (82 \%)\end{array}$ & Swedish \\
\hline $\mathrm{CRC}^{\mathrm{b}}(14)$ & $\begin{array}{l}\mathrm{CT}+\mathrm{TT} \\
\mathrm{CC}\end{array}$ & $\begin{array}{ll}31 & (16 \%) \\
16 & (10 \%)\end{array}$ & $\begin{array}{rr}45 & (18 \%) \\
1 & (0.7 \%)\end{array}$ & English \\
\hline $\operatorname{RCC}^{\mathrm{d}}(21)$ & $\mathrm{CT}+\mathrm{TT}$ & $144(90 \%)$ & $161(99.3 \%)$ & \\
\hline
\end{tabular}

${ }^{\mathrm{a} H N S C C}$, head and neck squamous cell carcinoma; ${ }^{\mathrm{b}} \mathrm{CRC}$, colorectal carcinoma; ${ }^{\mathrm{c} E S C C}$, esophageal squamous cell carcinoma and ${ }^{\mathrm{d}} \mathrm{RCC}$, renal cell carcinoma.

\section{Results}

HIF-1 a polymorphisms in cancer patients and health controls. The frequencies of $\mathrm{C} 1772 \mathrm{~T}$ and G1790A polymorphisms in breast cancer patients and case-matched healthy controls are shown in Table I. The genotype distribution of the $\mathrm{C} 1772 \mathrm{~T}$ in the breast cancer patients $(\mathrm{C} / \mathrm{C}=90 \%, \mathrm{C} / \mathrm{T}=8.9 \%, \mathrm{~T} / \mathrm{T}=1.1 \%)$, controls $(\mathrm{C} / \mathrm{C}=91.2 \%, \mathrm{C} / \mathrm{T}=8.8 \%)$ and the $\mathrm{G} 1790 \mathrm{~A}$ in the patients $(\mathrm{G} / \mathrm{G}=96.7 \%, \mathrm{G} / \mathrm{A}=3.3 \%)$, controls $(\mathrm{G} / \mathrm{G}=92.1 \%$, $\mathrm{G} / \mathrm{A}=6.9 \%, \mathrm{~A} / \mathrm{A}=1 \%)$ are noted. The allele distribution of $\mathrm{C} 1772 \mathrm{~T}$ in the breast cancer patients $(\mathrm{C}=94.4 \%, \mathrm{~T}=5.6 \%)$, healthy controls $(\mathrm{C}=95.6 \%, \mathrm{~T}=4.4 \%)$ and the $\mathrm{G} 1790 \mathrm{~A}$ in the patients $(\mathrm{G}=98.3 \%, \mathrm{~A}=1.7 \%)$ and healthy controls $(\mathrm{G}=95.6 \%$, $\mathrm{A}=4.4 \%$ ) was detected as indicated. We observed the genotype, allele distribution of the two polymorphisms (C1772T, G1790A) to not be different between breast cancer patients and healthy controls. Two polymorphisms of HIF- $1 \alpha$ were confirmed by germline origin of normal tissue within the same patients. Frequencies of C1772T or G1790A polymorphisms of HIF-1 $\alpha$ in various cancer patients and healthy controls are shown in Table II and Table III. In six other reported cancer studies of $\mathrm{C} 1772 \mathrm{~T}$ polymorphism $(10,12-15,21)$, two patterns were observed; a) patient groups with a CT or TT genotype are more elevated than in control 
Table III. Frequency of HIF-1 $\alpha$ polymorphism (G1790A) in a variety of cancers.

\begin{tabular}{|c|c|c|c|c|}
\hline Type of cancer & Genotype & Patients & Controls & Racial group \\
\hline $\begin{array}{l}\text { Breast cancer } \\
\text { (our result) }\end{array}$ & $\begin{array}{l}\mathrm{GG} \\
\mathrm{GA}+\mathrm{AA}\end{array}$ & $\begin{array}{rr}87 & (96.7 \%) \\
3 & (3.3 \%)\end{array}$ & $\begin{array}{r}94(92.1 \%) \\
8 \quad(7.9 \%)\end{array}$ & Korean \\
\hline HNSCC (10) & $\begin{array}{l}\mathrm{GG} \\
\mathrm{GA}+\mathrm{AA}\end{array}$ & $\begin{array}{r}51(92.7 \%) \\
4 \quad(7.3 \%)\end{array}$ & $\begin{array}{r}101(91.8 \%) \\
9 \quad(8.2 \%)\end{array}$ & Japanese \\
\hline CRC (14) & $\begin{array}{l}\mathrm{GG} \\
\mathrm{GA}+\mathrm{AA}\end{array}$ & $\begin{array}{rr}189 & (95 \%) \\
9 & (5 \%)\end{array}$ & $\begin{array}{rr}247 & (96 \%) \\
9 & (4 \%)\end{array}$ & Swedish \\
\hline RCC (21) & $\begin{array}{l}\mathrm{GG} \\
\mathrm{GA}+\mathrm{AA}\end{array}$ & $\begin{array}{l}65(44.5 \%) \\
81(55.5 \%)\end{array}$ & $\begin{aligned} 239 & (83 \%) \\
49 & (17 \%)\end{aligned}$ & English \\
\hline
\end{tabular}

Table IV. Association of HIF-1 $\alpha$ expression with clinicopathological features, biomarkers in patients with breast cancer $(\mathrm{n}=90)$.

\begin{tabular}{|c|c|c|c|}
\hline \multirow[b]{2}{*}{ Parameter } & \multicolumn{2}{|c|}{ HIF- $1 \alpha$ expression } & \multirow[b]{2}{*}{ P-value } \\
\hline & $\leq 5 \%(\%)$ & $>5 \%(\%)$ & \\
\hline \multicolumn{4}{|c|}{ Histological type } \\
\hline Ductal & $32(82.1 \%)$ & $45(88.2 \%)$ & \\
\hline Non-ductal & $7(17.9 \%)$ & $6(11.8 \%)$ & $\mathrm{NA}^{\mathrm{a}}$ \\
\hline \multicolumn{4}{|c|}{ Histological grade } \\
\hline I & $13(33.3 \%)$ & $3(5.9 \%)$ & \\
\hline II & $4(10.3 \%)$ & $14(27.5 \%)$ & \\
\hline III & $22(56.4 \%)$ & $34(66.7 \%)$ & 0.001 \\
\hline \multicolumn{4}{|c|}{ Lymph node metastasis } \\
\hline Negative & $23 \quad(59 \%)$ & $19(37.3 \%)$ & \\
\hline Positive & $16 \quad(41 \%)$ & $32(62.7 \%)$ & 0.041 \\
\hline \multicolumn{4}{|l|}{$\mathrm{ER}^{\mathrm{b}}$} \\
\hline Negative & $15(38.5 \%)$ & $22(43.1 \%)$ & \\
\hline Positive & $24(61.5 \%)$ & $29(56.9 \%)$ & 0.655 \\
\hline \multicolumn{4}{|l|}{$\mathrm{PR}^{\mathrm{c}}$} \\
\hline Negative & $23(59.0 \%)$ & $27(52.9 \%)$ & \\
\hline Positive & $16(41.0 \%)$ & $24(47.1 \%)$ & 0.568 \\
\hline \multicolumn{4}{|l|}{$\mathrm{HER}^{\mathrm{d}}$} \\
\hline Negative & $22(56.4 \%)$ & $29(56.9 \%)$ & \\
\hline Positive & $17(43.6 \%)$ & $22(43.1 \%)$ & 0.966 \\
\hline \multicolumn{4}{|l|}{ p53 } \\
\hline Negative & $28(71.8 \%)$ & $30(58.8 \%)$ & \\
\hline Positive & $11(28.2 \%)$ & $21(41.2 \%)$ & 0.203 \\
\hline \multicolumn{4}{|l|}{$\mathrm{Ki}-67$} \\
\hline$\leq 10$ & $25(64.1 \%)$ & $21(41.2 \%)$ & \\
\hline$>10 \%$ & $14(35.9 \%)$ & $30(58.8 \%)$ & 0.031 \\
\hline
\end{tabular}

Using the Chi-square test, p-values $<0.05$ were regarded as significant. P-value $<0.05$ is shown in bold; ${ }^{\mathrm{N} A}$, not applicable; ${ }^{\mathrm{b}} \mathrm{R}$, estrogen receptor; ${ }^{\mathrm{C}} \mathrm{PR}$, progesterone receptor and ${ }^{\mathrm{d}} \mathrm{HER} 2$, epidermal growth factor receptor type 2 .

groups (head and neck, esophagus, prostate cancer) and b) the CC genotype is more elevated in patient groups (renal, colorectal cancer). Based on our investigations in breast cancer patients, the CT or TT genotypes were more frequent in the patient than control group (Table II). In three reported studies of G1790A polymorphism $(10,14,21)$, GA or AA genotype in renal and colorectal cancers showed a higher frequency in patient than control groups. In contrast, the GG genotype in head and neck cancer showed a higher frequency in patient group. In our analysis in breast cancer, more GA or AA genotype were observed in the control group (Table III).

HIF-1 a expression, clinicopathological features and biomarkers. HIF-1 $\alpha$ was stained and assessed in breast cancer tissue of 90 patients. According to expression patterns, we subdivided staining distribution into positive and negative categories based on a 5\% cutoff value and observed $56.7 \%$ (51 of 90) positive and 43.3\% (39 of 90) negative cases (Table IV). The association between expression of HIF- $1 \alpha$ and clinicopathological features or biomarkers is shown in Table IV. For patients with breast cancer, elevated levels of HIF- $1 \alpha$ expression were significantly associated with high histological grade $(\mathrm{p}=0.001)$ and lymph node metastasis $(\mathrm{p}=0.041)$. In addition, the correlation between several biomarkers (ER, PR, HER2, p53, Ki-67), which are known to associate with patient prognosis in breast cancer and HIF-1 $\alpha$, are also presented in Table IV. Ki-67 expression levels $(\mathrm{p}=0.031)$ were positively associated with increased levels of HIF-1 $\alpha$; ER ( $\mathrm{p}=0.655), \operatorname{PR}(\mathrm{p}=0.568), \operatorname{HER} 2(\mathrm{p}=0.966)$ and $\mathrm{p} 53(\mathrm{p}=0.230)$, however, bore no relationship.

C1772T polymorphism, clinicopathological features and $H I F-1 \alpha$ expression. In the subjects heterozygous or homozygous for the T allele ( $\mathrm{n}=9)$, increased levels of HIF- $1 \alpha$ in $88.9 \%$ (8 of 9), a high histological grade (III) in $77.8 \%$ (7 of 9) and the presence of lymph node metastasis in $33.3 \%$ ( 3 of 9) were observed. The HIF-1 $\alpha$ overexpression $(p=0.040)$ and accumulation of p53 ( $=0.040)$ were significantly associated with the T1772 polymorphic allele (Table V), but ER $(p=0.830)$, PR $(p=0.157), \operatorname{HER} 2(p=0.523)$ and Ki-67 $(p=0.779)$ were not.

\section{Discussion}

The purpose of this study was to determine if the coding SNPs (C1772T and G1790A) of the HIF-1 $\alpha$ gene have frequency differences between patients and healthy controls and whether these SNPs may affect expression of HIF-1 $\alpha$ protein. 
Table V. Association of HIF-1 $\alpha$ polymorphism with clinicopathological features, biomarker, HIF-1 $\alpha$ expression in patients with breast cancer $(n=90)$.

\begin{tabular}{|c|c|c|c|}
\hline Parameter & $\mathrm{CC}(\%)$ & $\mathrm{CT}+\mathrm{TT}(\%)$ & P-value \\
\hline \multicolumn{4}{|c|}{ Histological grade } \\
\hline I & $15(18.5 \%)$ & $1(11.1 \%)$ & \\
\hline II & $17(21.0 \%)$ & $1(11.1 \%)$ & \\
\hline III & $49(60.5 \%)$ & $7(77.8 \%)$ & 0.596 \\
\hline \multicolumn{4}{|c|}{ Lymph node metastasis } \\
\hline Negative & $36(44.4 \%)$ & $6(66.7 \%)$ & \\
\hline Positive & $45(55.6 \%)$ & $3(33.3 \%)$ & 0.205 \\
\hline \multicolumn{4}{|c|}{ HIF-1 $\alpha$ expression } \\
\hline$\leq 5 \%$ & $38(46.9 \%)$ & $1(11.1 \%)$ & \\
\hline$>5 \%$ & $43(53.1 \%)$ & $8(88.9 \%)$ & 0.040 \\
\hline \multicolumn{4}{|l|}{ ER } \\
\hline Negative & $33(40.7 \%)$ & $4(44.4 \%)$ & \\
\hline Positive & $48(59.3 \%)$ & $5(55.6 \%)$ & 0.830 \\
\hline \multicolumn{4}{|l|}{ PR } \\
\hline Negative & $47(58.0 \%)$ & $3(33.3 \%)$ & \\
\hline Positive & $34(42.0 \%)$ & $6(66.7 \%)$ & 0.157 \\
\hline \multicolumn{4}{|l|}{ HER } \\
\hline Negative & $45(55.6 \%)$ & $6(66.7 \%)$ & \\
\hline Positive & $36(44.4 \%)$ & $3(33.3 \%)$ & 0.523 \\
\hline \multicolumn{4}{|l|}{ p53 } \\
\hline Negative & $55(67.9 \%)$ & $3(33.3 \%)$ & \\
\hline Positive & $26(32.1 \%)$ & $6(66.7 \%)$ & 0.040 \\
\hline \multicolumn{4}{|l|}{ Ki-67 } \\
\hline$\leq 10 \%$ & $41(50.6 \%)$ & $5(55.6 \%)$ & \\
\hline$>10 \%$ & $40(49.4 \%)$ & $4(44.4 \%)$ & 0.779 \\
\hline
\end{tabular}

The role of HIF-1 $\alpha$ in cancer has been demonstrated through clarification of the structural and functional relationships between HIF- $1 \alpha$ and pVHL (22). Both Pro402 and Pro564 have been shown to be key amino acids in oxygen-dependent regulation of HIF-1 $\alpha$ protein stability (23). Polymorphisms of C1772T (P582S) and G1790A (A588T) adjacent to Pro564, as identified for the human HIF-1 $\alpha$ gene, have been shown to have significantly higher transcriptional activities and involved in enhanced angiogenesis when compared to wild-type HIF-1 $\alpha$ (10). It was also determined that the increased transcriptional activity reflects increased protein expression in cells that have been transfected with P582S mutants (11).

Recent research has identified two SNPs (C1772T and G1790A) as valuable candidate tools to diagnose cancer, however, they remain the subject of ongoing debate involving a variety of cancers and involving multiple research groups (Table II and Table III). In a head and neck cancer study, Tanimoto et al reported that CT or GA genotypes correlate with significantly elevated transcription activity (10) while in a renal cancer study, Ollerenshaw et al reported that either CC or GA genotype of HIF-1 $\alpha$ may confer susceptibility to cancer (21). For colorectal cancer, Kuwai et al suggest that the CT genotype has no involvement in either cancer progression or metastasis (13) whereas Fransen et al reported that for CT or TT, GA genotype displayed a significantly higher risk to developing ulcerative colorectal cancer (14). Previously, in an esophageal cancer report, the CT genotype was associated with larger tumors and higher rates of lymph node metastasis (15). In the case of androgen-independent prostate cancer, Chau et al observed that a CT or TT genotype may contribute to the progression or metastasis of cancer (12). According to our analysis of these frequencies as reported by others, we confirmed that our result (C1772T or G1790A) for breast cancer patients is similar to that of head and neck, esophageal cancers. The genotype frequencies of CT or TT observed in the patients and healthy controls were 10 vs. $8.8 \%$ (breast cancer; Korean), 11.6 vs. 10.6\% (ESCC; Chinese) and 18.2 vs. $10.9 \%$ (HNSCC; Japanese) whereas the frequency in renal cancer (English) indicated 90.0 vs. 99.3\% (Table II). In addition, the genotype frequencies of GA or AA observed in the patients and healthy controls were 3.3 vs. $7.9 \%$ (breast cancer; Korean) and 7.3 vs. 8.2\% (HNSCC; Japanese). In contrast, the frequency in renal cancer (English) shows 55.5 vs. $17 \%$ (Table III). Based on these results, we concluded that there is a difference of frequency pattern in HIF- $1 \alpha$ polymorphisms between Asian and European populations. We suggest, therefore, that HIF- $1 \alpha$ genotype distribution is associated with different racial groups.

Induction of HIF-1 $\alpha$ expression appears to be a crucial step in a tissues response to hypoxia. The response occurs via increased mRNA expression, protein stabilization, nuclear 
localization and augmented activity of its transcriptional activation domains (24). An increase in tissue concentration of HIF-1 $\alpha$ has recently been demonstrated in association with a more aggressive phenotype of cancer cells and with progression of human malignant diseases $(7,22,25,26)$. In particular, for breast cancer, overexpression of HIF-1 $\alpha$ was associated with increased proliferation and poor differentiation (19). As shown in Table IV, HIF-1 $\alpha$ overexpression occurred in $56.7 \%$ (51 of 90 ) of our breast cancer cases according to immunochemical staining. Further, elevated levels of HIF-1 $\alpha$ expression were significantly associated with a high histological grade $(\mathrm{p}=0.001)$ and metastasis to lymph nodes $(\mathrm{p}=0.041)$. We also determined a positive association between expression of HIF-1 $\alpha$ and Ki-67 (Table IV). Indeed, Ki-67 overexpression in the S or G1-G2 phase indicates a high proliferation rate and thus poor prognosis (27). In the case of an HIF-1 $\alpha$ positive group, there seems to be a significant association with increased levels of Ki-67 as a marker of proliferation (Table IV). These results are consistent with previous reports of HIF- $1 \alpha$ staining in breast cancer $(19,28-30)$. Thus, we suggest that HIF- $1 \alpha$ is involved in unfavorable prognosis for Korean breast cancer patients.

In the subgroup of patients carrying the polymorphic T1772 allele ( $\mathrm{n}=9)$, we found a high histological grade (III) in $77.8 \%$ (7 of 9). In addition, we determined a significant association between the $\mathrm{C} 1772 \mathrm{~T}$ polymorphism and expression of HIF- $1 \alpha(\mathrm{p}=0.040)$ (Table V). These results are consistent with previous findings in lung cancer patients demonstrating that CT or TT cases have an HIF-1 $\alpha$ overexpression of $81.8 \%$ (9 of 11) (31). Although a significant association between HIF- $1 \alpha$ overexpression and p53 accumulation were not found, positive relations were found in accordance with the findings of Bos et al and Zhong et al in colon and breast cancers $(2,29)$. We also found a significant association between $\mathrm{C} 1772 \mathrm{~T}$ polymorphism and $\mathrm{p} 53$ expression $(\mathrm{p}=0.04)$. As a matter of fact, tumor suppressor gene p53 represses HIF-1-stimulated transcription and HIF-1 and wt p53 both are up-regulated in hypoxic condition (32). Although the G1790A polymorphism was studied, the GA genotype seems not to have significant meaning (data not shown). Finally, patients carrying the polymorphic T1772 allele likely result in a poorer prognosis and presumably more aggressive tumors.

In conclusion, our study demonstrated, for the first time, that the polymorphism C1772T of HIF-1 $\alpha$ gene increase expression of HIF- $1 \alpha$ protein in breast cancer. We have determined that HIF-1 $\alpha$ overexpression depends on cancer progression and Ki-67 as a marker of proliferation. Moreover, we suggest that the polymorphic T1772 allele with HIF-1 $\alpha$ overexpression may contribute to development of higher grade cancers. We stress the need for $\mathrm{C} 1772 \mathrm{~T}$ (P582S) polymorphism and expression of HIF-1 $\alpha$ relationship be further assessed as a risk factor for cancer development and predictive marker of poor prognosis in breast cancer patients.

\section{Acknowledgements}

This study was supported by a grant from the Korea Science \& Engineering Foundation (NO. R13-2002-020-01001-0) and by the Korea Research Foundation Grant KRF-2001-042F00063.

\section{References}

1. Vaupel P: The role of hypoxia-induced factors in tumor progression. Oncologist 5: 10-17, 2004.

2. Zhong H, De Marzo AM, Laughner E, Lim M, Hilton DA, Zagzag D, Buechler P, Isaacs WB, Semenza GL and Simons JW: Overexpression of hypoxia-inducible factor 1alpha in common human cancers and their metastases. Cancer Res 59: 5830-5835, 1999.

3. Maxwell PH, Wiesener MS, Chang GW, Clifford SC, Vaux EC, Cockman ME, Wyk off CC, Pugh CW, Maher ER and Ratcliffe PJ: The tumour suppressor protein VHL targets hypoxia-inducible factors for oxygen-dependent proteolysis. Nature 399: 271-275, 1999.

4. Semenza GL: HIF-1 and human disease: one highly involved factor. Genes Dev 14: 1983-1991, 2000.

5. Semenza GL: Targeting HIF-1 for cancer therapy. Nat Rev Cancer 3: 721-732, 2003.

6. Kaelin WG Jr: Molecular basis of the VHL hereditary cancer syndrome. Nat Rev Cancer 2: 673-682, 2002.

7. Wang GL, Jiang BH, Rue EA and Semenza GL: Hypoxiainducible factor 1 is a basic-helix-loop-helix-PAS heterodimer regulated by cellular O2 tension. Proc Natl Acad Sci USA 92: 5510-5514, 1995.

8. Min JH, Yang H, Ivan M, Gertler F, Kaelin WG Jr and Pavletich NP: Structure of an HIF-1alpha-pVHL complex: hydroxyproline recognition in signaling. Science 296: 1886-1889, 2002.

9. Clifford SC, Astuti D, Hooper L, Maxwell PH, Ratcliffe PJ and Maher ER: The pVHL-associated SCF ubiquitin ligase complex: molecular genetic analysis of elongin $\mathrm{B}$ and $\mathrm{C}, \mathrm{Rbx} 1$ and HIF-1alpha in renal cell carcinoma. Oncogene 20: 5067-5074, 2001.

10. Tanimoto K, Yoshiga K, Eguchi H, Kaneyasu M, Ukon K, Kumazaki T, Oue N, Yasui W, Imai K, Nakachi K, et al: Hypoxia-inducible factor-1alpha polymorphisms associated with enhanced transactivation capacity, implying clinical significance. Carcinogenesis 24: 1779-1783, 2003.

11. Fu XS, Choi E, Bubley GJ and Balk SP: Identification of hypoxia-inducible factor-1alpha (HIF-1alpha) polymorphism as a mutation in prostate cancer that prevents normoxia-induced degradation. Prostate 63: 215-221, 2005

12. Chau CH, Permenter MG, Steinberg SM, Retter AS, Dahut WL, Price DK and Figg WD: Polymorphism in the hypoxiainducible factor 1alpha gene may confer susceptibility to androgen-independent prostate cancer. Cancer Biol Ther 4: 1222-1225, 2005

13. Kuwai T, Kitadai Y, Tanaka S, Kuroda T, Ochiumi T, Matsumura S, Oue N, Yasui W, Kaneyasu M, Tanimoto K, et al: Single nucleotide polymorphism in the hypoxia-inducible factor-1alpha gene in colorectal carcinoma. Oncol Rep 12: 1033-1037, 2004.

14. Fransen K, Fenech M, Fredrikson M, Dabrosin C and Soderkvist P: Association between ulcerative growth and hypoxia inducible factor-1alpha polymorphisms in colorectal cancer patients. Mol Carcinog 45: 833-840, 2006.

15. Ling TS, Shi RH, Zhang GX, Zhu H, Yu LZ and Ding XF: Common single nucleotide polymorphism of hypoxia-inducible factor-1alpha and its impact on the clinicopathological features of esophageal squamous cell carcinoma. Chin J Dig Dis 6: $155-158,2005$.

16. Brizel DM, Scully SP, Harrelson JM, Layfield LJ, Bean JM, Prosnitz LR and Dewhirst MW: Tumor oxygenation predicts for the likelihood of distant metastases in human soft tissue sarcoma. Cancer Res 56: 941-943, 1996.

17. Nordsmark M, Overgaard M and Overgaard J: Pretreatment oxygenation predicts radiation response in advanced squamous cell carcinoma of the head and neck. Radiother Oncol 41: 31-39, 1996.

18. Hockel M, Schlenger K, Knoop C and Vaupel P: Oxygenation of carcinomas of the uterine cervix: evaluation by computerized O2 tension measurements. Cancer Res 51: 6098-6102, 1991.

19. Bos R, Zhong H, Hanrahan CF, Mommers EC, Semenza GL, Pinedo HM, Abeloff MD, Simons JW, van Diest PJ and van der Wall E: Levels of hypoxia-inducible factor-1 alpha during breast carcinogenesis. J Natl Cancer Inst 93: 309-314, 2001. 
20. Vleugel MM, Greijer AE, van der Wall E and van Diest PJ: Mutation analysis of the HIF-1alpha oxygen-dependent degradation domain in invasive breast cancer. Cancer Genet Cytogenet 163: 168-172, 2005.

21. Ollerenshaw M, Page T, Hammonds $J$ and Demaine A: Polymorphisms in the hypoxia inducible factor-1alpha gene (HIF1A) are associated with the renal cell carcinoma phenotype. Cancer Genet Cytogenet 153: 122-126, 2004

22. Ivan M, Kondo K, Yang H, Kim W, Valiando J, Ohh M, Salic A, Asara JM, Lane WS and Kaelin WG Jr: HIFalpha targeted for VHL-mediated destruction by proline hydroxylation: implications for O2 sensing. Science 292: 464-468, 2001.

23. Elkins JM, Hewitson KS, McNeill LA, Seibel JF, Schlemminger I, Pugh CW, Ratcliffe PJ and Schofield CJ: Structure of factor-inhibiting hypoxia-inducible factor (HIF) reveals mechanism of oxidative modification of HIF-1 alpha. J Biol Chem 278: 1802-1806, 2003.

24. Semenza GL: Regulation of mammalian O2 homeostasis by hypoxia-inducible factor 1. Annu Rev Cell Dev Biol 15: 551-578, 1999.

25. Krieg M, Haas R, Brauch H, Acker T, Flamme I and Plate KH: Up-regulation of hypoxia inducible factors HIF-1alpha and HIF-2alpha under normoxic conditions in renal carcinoma cells by von Hippel-Lindau tumor suppressor gene loss of function. Oncogene 19: 5435-5443, 2000

26. Jaakkola P, Mole DR, Tian YM, Wilson MI, Gielbert J, Gaskell SJ, Kriegsheim Av, Hebestreit HF, Mukherji M, Schofield CJ, et al: Targeting of HIF-alpha to the von HippelLindau ubiquitylation complex by $\mathrm{O} 2$-regulated prolyl hydroxylation. Science 292: 468-472, 2001.
27. Van Diest PJ, Brugal G and Baak JP: Proliferation markers in tumours: interpretation and clinical value. J Clin Pathol 51: 716-724, 1998.

28. Bos R, van der Groep P, Greijer AE, Shvarts A, Meijer S, Pinedo HM, Semenza GL, van Diest PJ and van der Wall E: Levels of hypoxia-inducible factor-1alpha independently predict prognosis in patients with lymph node negative breast carcinoma. Cancer 97: 1573-1581, 2003.

29. Bos R, van Diest PJ, van der Groep P, Shvarts A, Greijer AE and van der Wall E: Expression of hypoxia-inducible factor1 alpha and cell cycle proteins in invasive breast cancer are estrogen receptor related. Breast Cancer Res 6: R450-R459, 2004

30. Kuijper A, van der Groep P, van der Wall E and van Diest PJ Expression of hypoxia-inducible factor 1 alpha and its downstream targets in fibroepithelial tumors of the breast. Breast Cancer Res 7: R808-R818, 2005.

31. Koukourakis MI, Papazoglou D, Giatromanolaki A, Panagopoulos I, Maltezos E, Harris AL, Gatter KC and Sivridis E: C2028T polymorphism in exon 12 and dinucleotide repeat polymorphism in intron 13 of the HIF-1alpha gene define HIF-1alpha protein expression in non-small cell lung cancer. Lung Cancer 53: 257-262, 2006.

32. Blagosklonny MV, An WG, Romanova LY, Trepel J, Fojo T and Neckers L: p53 inhibits hypoxia-inducible factor-stimulated transcription. J Biol Chem 273: 11995-11998, 1998. 